\title{
CIRCADIAN RHYTHMS OF LEUKEMIA INHIBITORY FACTOR IN THE BLOOD OF PATIENTS WITH ESSENTIAL HYPERTENSION
}

Radaeva $\mathrm{OA}^{1}{ }^{\square}$, Simbirtsev $\mathrm{AS}^{2}$, Gromova $\mathrm{EV}^{1}$, Iskandiarova $\mathrm{MS}^{1}$, Belyaeva $\mathrm{SV}^{3}$

1 Institute of Medicine, National Research Mordovia State University, Saransk, Russia

2 State Research Institute of Highly Pure Biopreparations, FMBA, Saint Petersburg, Russia

${ }^{3}$ North Caucasus Health Center, Pyatigorsk, Russia

Leukemia inhibitory factor (LIF) exerts multidirectional effects in the setting of essential hypertension (EH). There is a mounting body of evidence refuting the postulate about identical STAT3 signaling in cardiomyocytes and endothelial/smooth muscle cells, which is important in the situation of extended exposure to gp 130 ligands (LIF in particular). At the same time, there are no reports on the circadian dynamics of peripheral blood LIF concentrations and possible secondary changes to the pathophysiological effects of this cytokine. This study aimed to analyze the circadian dynamics of LIF concentrations in the peripheral blood serum measured at 5 different time points in patients with stage II EH in the presence/absence of antihypertensive therapy and their relationship with the frequency of complications developing within a 5-year follow-up. Blood serum LIF was measured in 60 patients with stage II EH using ELISA at 8:00, 14:00, 20:00, 2:00, and 8:00 o'clock before putting the patients on antihypertensive therapy and one year after its onset. The identified patterns of diurnal LIF concentrations (a rise by $\geq 15 \%$ at 20:00, $p<0.001$; a further rise by $\geq 22 \%$ peaking at 2:00, $p<0.001$ relative to the values at 8:00) can be regarded as pathologic; their persistence after one year of antihypertensive therapy is a sign of $\mathrm{EH}$ progression and puts the patients at 6 -fold risk for cardiovascular complications, including myocardial infarction and acute cerebrovascular events.

Keywords: LIF, leukemia inhibitory factor, cytokine circadian rhythms, essential hypertension

Author contribution: Radaeva OA designed the study, analyzed the results, formulated the conclusions and wrote the manuscript; Simbirtsev AS formulated the objective of the study, revised its conclusions and the manuscript itself; Gromova EV designed the study, carried out laboratory tests, and contributed to writing the manuscript; Iskandiarova MS analyzed the literature, supervised blood collection, followed up with the patients, contributed to writing the manuscript; Belyaeva SV analyzed the literature, supervised blood collection, followed up with the patients.

Compliance with ethical standards: the study was approved by the Ethics Committee of National Research Mordovia State University (Protocol No. 12 dated December 14, 2008). Written informed consent was obtained from all study participants. Blood samples were collected in compliance with the Declaration of Helsinki (2008), the protocol of European Convention on Human Rights and Biomedicine (1999) and the additional protocol to the Convention on Human Rights and Biomedicine concerning Biomedical Research (2005)

$\triangle$ Correspondence should be addressed: Olga A. Radaeva Ulianova, 26a, Saransk, 430000; vtlbwbyf_79@mail.ru

Received: 11.03.2020 Accepted: 25.03.2020 Published online: 28.03.2020

DOI: $10.24075 /$ brsmu.2020.017

\section{ИЗМЕНЕНИЕ СУТОЧНОГО РИТМА СОДЕРЖАНИЯ ИНГИБИРУЮЩЕГО ЛЕЙКЕМИЮ ФАКТОРА В КРОВИ БОЛЬНЫХ ЭССЕНЦИАЛЬНОЙ ГИПЕРТЕНЗИЕЙ}

\section{О. А. Радаева ${ }^{1 凶}$ А. С. Симбирцев², Е. В. Громова ${ }^{1}$, М. С. Искандярова', С. В. Беляева ${ }^{3}$}

${ }^{1}$ Медицинский институт Национального исследовательского Мордовского государственного университета имени Н. П. Огарева, Саранск, Россия

2 Государственный научно-исследовательский институт особо чистых биопрепаратов Федерального медико-биологического агентства, Санкт-Петербург, Россия

${ }^{3}$ Санаторно-курортный комплекс «Северокавказский», Пятигорск, Россия

Ингибирующий лейкемию фактор (LIF) обладает неоднозначными физиологическими эффектами при эссенциальной артериальной гипертензии (ЭАГ). Опровергается постулат об идентичности STAT3-сигнализации в клетках миокарда и эндотелиальных/гладкомышечных клетках, что значимо при длительном воздействии цитокинов-лигандов gр 130 (в частности LIF). При этом отсутствуют данные о суточных характеристиках содержания LIF в крови с потенциальными вторичными изменениями его патофизиологических эффектов. Целью исследования было проанализировать особенности суточных ритмов содержания LIF в сыворотке периферической крови больных ЭАГ II стадии, определенного в пяти временны́х точках в зависимости от применения гипотензивной терапии и частоты развития осложнений в последующие 5 лет наблюдения. У 60 больных ЭАГ II стадии иммуноферментным методом определяли уровни LIF в сыворотке периферической крови в 8.00, 14.00, 20.00, 2.00, 8.00 ч до и после года гипотензивной терапии. Выявленные закономерности суточного ритма содержания LIF в сыворотке крови больных ЭАГ II стадии в виде увеличения в 20.00 ч на 15\% (p < 0,001) и выше с максимальным ростом в 2.00 ч на 22\% ( $<$ 0,001) и более при сравнении с индивидуальным уровнем в 8.00 ч можно характеризовать как патологические, а их сохранение после года гипотензивной терапии служит признаком прогредиентного течения гипертензии с повышением риска развития сердечно-сосудистых осложнений (инсаркт миокарда, острое нарушение мозгового кровообращения) в 6 раз

Ключевые слова: LIF, ингибирующий лейкемию фактор, суточный ритм цитокинов, эссенциальная гипертензия

Вклад авторов: О. А. Радаева - разработка дизайна исследования, анализ результатов, формулировка выводов, оформление рукописи; А. С. Симбирцев - формулирование цели исследования, корректирование выводов и итогового варианта рукописи; Е. В. Громова - разработка дизайна исследования, проведения лабораторного этапа исследования, оформление рукописи; М. С. Искандярова - работа с литературой, контроль забора материала, динамическое наблюдение за пациентами, работа над первым вариантом рукописи; С. В. Беляева - работа с литературой, контроль забора материала и участие в наблюдении за пациентами.

Соблюдение этических стандартов: исследование одобрено этическим комитетом Мордовского государственного университета имени Н. П. Огарева (протокол № 12 от 14 декабря 2008 г.). Все пациенты подписали добровольное информированное согласие. Получение биологического материала для исследования (кровь) производили с учетом положений Хельсинской декларации ВМА (2008 г.) и протокола Конвенции Совета Европы о правах человека и биомедицине (1999) с учетом дополнительного протокола к Конвенции по правам человека и биомедицине в области биомедицинских исследований (2005).

Для корреспонденции: Ольга Александровна Радаева ул. Ульянова, д. 26а, г. Саранск, 430000; vtlbwbyf_79@mail.ru

Статья получена: 11.03.2020 Статья принята к печати: 25.03.2020 Опубликована онлайн: 28.03.2020

DOI: 10.24075/vrgmu.2020.017 
Leukemia inhibitory factor (LIF) exerts a vast variety of physiological effects through specific LIF receptors located on the membranes of endothelial cells, monocytes, neurons and other cells [1] in physiologically relevant quantities [2]. Although LIF signaling pathways through JAK/STAT (Janus kinase/signal transducer and activator of transcription), MAPK (mitogen-activated protein kinases) and PI3K (phosphoinositide 3-kinases) are stable, the effects LIF induces in different cell types can be opposite, including both stimulation and inhibition of cell differentiation and survival. There is a lot of debate as to how LIF affects the arterial wall in patients with essential hypertension $(\mathrm{EH})$ since the mechanism underlying STAT3 activation is redox-sensitive [3] and its directionality changes in the setting of chronically elevated blood pressure, distorting LIF effects. There is a growing body of evidence refuting the postulate about identical STAT3 signaling in cardiomyocytes and endothelial/smooth muscle cells, which is important in the situation of extended exposure to gp 130 ligands (LIF in particular) [4]. Research has demonstrated that factors implicated in $\mathrm{EH}$ progression and the risk of $\mathrm{EH}$ complications are dependent on time of day [5], proving the significance of investigating both the levels of cytokines involved and diurnal variations in their concentrations.

The aim of this study was to analyze the circadian rhythms of LIF concentrations in the peripheral blood serum measured at 5 different time points $(8: 00,14: 00,20: 00,2: 00$, and 8:00 o'clock) in patients with stage $\mathrm{IIH}$ in the presence/absence of antihypertensive therapy and their relationship with the frequency of complications developing within a 5-year follow-up.

\section{METHODS}

In 2008 through 2019, a study called Cytokines in the pathogenesis of essential hypertension was carried out at the Institute of Medicine (National Research Mordovia State University) and the Regional Vascular Center (Republican Clinical Hospital № 4).

As part of the study, a group of 60 patients with stage ॥ $\mathrm{EH}$ (30 men and 30 women) was formed to explore how LIF production changed over a 24-hour cycle. The following inclusion criteria were applied: individuals with stage $\| \mathrm{EH}$, born in 1955-1956, who had a 10- to 14-year history of the disease, were not receiving any antihypertensive therapy at the beginning of the study but were subsequently put on therapy (ACE inhibitors \pm diuretics) to achieve a target blood pressure, as recommended by the Russian guidelines on the diagnosis and treatment of hypertension (2010) [6], which they did within a year that followed; total cholesterol $<5.0 \mathrm{mmol} / \mathrm{L}$, $\mathrm{LDL}<3.0 \mathrm{mmol} / \mathrm{L}, \mathrm{HDL}>1.0 \mathrm{mmol} / \mathrm{L}$, triglycerides $<1.7 \mathrm{mmol} / \mathrm{L}$, glucose $<5.5 \mathrm{mg} / \mathrm{dl}$, BMl $<30 \mathrm{~kg} / \mathrm{m}^{2}$; comparable risk of developing EH-related complications. Patients with hypertension-associated comorbidities, types 1 or 2 diabetes mellitus, autoimmune disorders, allergies, or symptomatic hypertension were excluded from the study. The control group consisted of 30 seemingly healthy individuals (15 men and 15 women) with systolic BP of 100 to $130 \mathrm{mmHg}$ and diastolic BP of 70 to $89 \mathrm{mmHg}$; the groups were comparable in terms of age and blood biochemistry.

Blood samples $(2 \mathrm{ml})$ were collected prior to the onset of antihypertensive therapy (2014) and one year after the start of treatment (2015) at 8:00, 14:00, 20:00, 2:00, and 8:00 o'clock (the fasting period was at least 6 hours). The time points were selected based on the results of our pilot study (blood samples had been collected from 7 individuals at 7:00, 8:00, 10:00, 12:00, 14:00, 16:00, 18:00, 20:00, 22:00, 00:00, 2:00, 4:00, 6:00, 7:00, and 8:00 o'clock). Time elapsed from sample collection to sample freezing was $60 \mathrm{~min}$. Serum LIF concentrations were measured using ELISA kits (Bender MedSystems; USA).

Follow-up phone interviews were conducted annually (20142019) to obtain information about possible complications, such as myocardial infarction (MI), acute cerebrovascular events (ACVE) and transient ischemic attacks (TIA), which were subsequently confirmed by clinical and diagnostic tests, including ECG, echocardiography, troponin tests, brain CT scans.

The obtained data were processed in Statistica 10.0 (Stat Soft; USA). Normality of data distribution was analyzed using the one-sample Kolmogorov-Smirnov test. Based on the obtained results, we used the paired t-test to compare the results of pre-treatment blood tests taken at 8:00, 14:00, 20:00, 2:00, and 8:00 o'clock in the group of patients with stage II EH; the Wilcoxon test was applied to compare the data in the group of patients on antihypertensive therapy one year after its onset and also in healthy controls. Intergroup comparison was carried

Table 1. LIF concentrations (pg/ml) in the peripheral blood serum in patients with stage II EH at 8:00, 14:00, 20:00, 2:00, and 8:00 o'clock (next day) in the absence/ presence of antihypertensive therapy in patients with or without cardiovascular complications developed in the 5-year follow-up period (Me (Q25\%-Q75\%))

\begin{tabular}{|c|c|c|c|c|c|c|}
\hline Groups & & $\begin{array}{l}8.00 \\
\text { (day } 1)\end{array}$ & $\begin{array}{l}14.00 \\
\text { (day } 1)\end{array}$ & $\begin{array}{l}20.00 \\
\text { (day } 1)\end{array}$ & $\begin{array}{c}2.00 \\
\text { (day 2) }\end{array}$ & $\begin{array}{c}8.00 \\
\text { (day 2) }\end{array}$ \\
\hline $\begin{array}{l}\text { Patients with EH (before therapy), } \\
n=60\end{array}$ & $a$ & 7.51 [6.58-8.34] & $7.58[6.47-8.41]$ & $\begin{array}{l}9.02[7.52-9.73] \\
\quad{ }^{*} 8.00 .14 .00\end{array}$ & $\begin{array}{c}10.1[9.44-11.8] \\
* 8.00 .14 .00 .20 .00\end{array}$ & $\begin{array}{l}7.53[6.65-8.22] \\
{ }^{*} 20.00 .2 .00\end{array}$ \\
\hline \multirow[t]{2}{*}{$\begin{array}{l}\text { Healthy controls, } \\
n=30\end{array}$} & $b$ & $1.41[1.02-1.83]$ & 1.38 [1.04-1.79] & $1.45[1.06-1.78]$ & $1.42[1.03-1.81]$ & 1.37 [0.99-1.79] \\
\hline & & $p(b-a)<0.001$ & $p(b-a)<0.001$ & $p(b-a)<0.001$ & $p(b-a)<0.001$ & $p(b-a)<0.001$ \\
\hline \multirow[t]{2}{*}{$\begin{array}{l}\text { Patients with } \mathrm{EH} \text { (one year in treatment), } \\
n=60, \text { of them: }\end{array}$} & c & 7.54 [6.57-8.38] & 7.61 [6.53-8.44] & $\begin{array}{l}8.95[7.63-9.58] \\
{ }^{*} 8.00 .14 .00\end{array}$ & $\begin{array}{l}7.62[6.84-8.63] \\
' 8.00 * 20.00\end{array}$ & $\begin{array}{c}7.58[6.62-8.31] \\
* 20.00 \\
\end{array}$ \\
\hline & & $\begin{array}{l}p(c-a)>0.05 \\
p(c-b)<0.001\end{array}$ & $\begin{array}{l}p(c-a)>0.05 \\
p(c-b)<0.001\end{array}$ & $\begin{array}{l}p(c-a)>0.05 \\
p(c-b)<0.001\end{array}$ & $\begin{array}{l}p(c-a)<0.001 \\
p(c-b)<0.001\end{array}$ & $\begin{array}{c}p(c-a)<0.05 \\
p(c-b)<0.001\end{array}$ \\
\hline $\begin{array}{l}\text { 5-year follow-up - Ml, ACVE, } \\
n=15\end{array}$ & $c 1$ & 7.66 [6.68-8.22] & 7.59 [6.49-8.37] & $\begin{array}{l}9.01[7.56-9.61] \\
{ }^{*} 8.00 .14 .00\end{array}$ & $\begin{array}{c}9.69[8.91-9.98] \\
* \\
* 8.00 .14 .00 .20 .00\end{array}$ & $\begin{array}{l}7.72[6.71-8.17] \\
{ }^{*} 20.00 \cdot 2.00\end{array}$ \\
\hline \multirow[t]{2}{*}{$\begin{array}{l}5 \text {-year follow-up - no } \\
\text { complications, } n=45\end{array}$} & $c 2$ & 7.58 [6.52-8.41] & 7.62 [6.5-8.42] & $\begin{array}{l}8.79[7.98-9.62] \\
{ }^{*} 8.00 .14 .00\end{array}$ & $\begin{array}{l}7.55[6.93-8.21] \\
* 20.00\end{array}$ & $\begin{array}{c}7.36[6.51-8.24] \\
* 20.00\end{array}$ \\
\hline & & $p(c 2-c 1)>0.05$ & $p(c 2-c 1)>0.05$ & $p(c 2-c 1)>0.05$ & $p(c 2-c 1)<0.001$ & $p(c 2-c 1)>0.05$ \\
\hline
\end{tabular}

Note: significant for comparisons with the specified time of blood collection or the group $(a, b, c, c 1, c 2){ }^{*}-p<0.001 ; \wedge-p<0.01 ;{ }^{*}-p<0.05$. The paired t-test was applied for intragroup comparison of pretreatment results obtained at 8:00, 14:00, 20:00, 2:00 and 8:00 o'clock. The Wilcoxon test was applied for intragroup comparison in the group of patients after one year of treatment and in the healthy controls. The Mann-Whitney U test was applied to compare independent samples. The Wilcoxon test was applied to compare dependent samples. 
out using the Mann-Whitney $U$ (for independent samples) and the Wilcoxon test (for dependent samples). Below, the data are presented as a median (Me) and percentiles (Q0.25-Q0.75). When comparing the subgroups, the Bonferroni correction for multiple comparisons was applied, ensuring the reliability of the statistical data. We calculated the absolute and relative risks of developing $\mathrm{MI}$ and ACVE, 95\% Cl, sensitivity and specificity. The analysis was aided by Fisher's exact test $(\varphi)$ and Pearson's correlation coefficient $\left(\mathrm{C}^{\prime}\right)$ were used.

\section{RESULTS}

The analysis revealed significant qualitative and quantitative differences in the circadian rhythms of blood serum LIF between the control group and the patients with stage II $\mathrm{EH}$ and a 10-14-year history of the disease who were not on antihypertensive therapy at the beginning of the study. In patients with stage II EH, LIF levels measured at 8:00, 14:00, 20:00 and 2:00 o'clock were 5-7.5 times higher ( $p<0.001$ ) than in the healthy individuals (Table 1). In the group of patients with $\mathrm{EH}$, a significant increase in LIF levels relative to 8:00 measurements (by 20.1\% (16.7-24.3\%); $p<0.001$ ) was observed at 20:00, peaking at 2:00 (an increase by 34\% (25.7-43\%); $p<0.001)$. Importantly, in the group of healthy controls, LIF levels did not change at 14:00, 20:00 and 2:00 o'clock relative to their initial values at 8:00 $(p>0.05)$. After being on antihypertensive therapy for one year, the patients with stage II EH who had achieved their target blood pressure demonstrated no decline in LIF concentrations at 8:00, 14:00 and 20:00 o'clock in comparison with pretreatment values $(p<0.01)$, but the circadian rhythm of the cytokine was different. In the patients who had been receiving antihypertensive therapy and had achieved the desired blood pressure, blood serum LIF peaked at 20:00; measurements taken at 2:00 showed a decline in LIF concentrations (Table 2) in comparison with the pretreatment period. In the group of patients undergoing treatment, the distribution of data differed from Gauss-Laplace distribution, which prompted us to analyze LIF circadian rhythms for each individual patient in order to identify the criteria for heterogeneity. We found that 22 patients undergoing antihypertensive therapy who had achieved the target blood pressure had the same circadian rhythms of blood serum LIF as before therapy (a rise at 20:00 with a peak at 2:00 and a decline at 8:00; see Table 2).

The analysis of data obtained during the follow-up observation from the patients undergoing antihypertensive therapy who had partially recovered normal LIF dynamics (a decline in LIF concentrations at 2:00) revealed that only 4 of 42 patients had developed ACVE or MI within a 5-year follow-up period (the absolute risk of complications was 9.5\% (0.63-18.4\%)). In the group of patients with persisting pathological diurnal rhythms of serum LIF (a rise at 20:00, a peak at 2:00 and a return to morning levels at 8:00), 11 of 18 patients had developed complications (ACVE, MI); in this group, the absolute risk of complications was $61.1 \%$ (38.6-83.6\%). The risk ratio between these two groups was 6.41 (2.35-17.5\%); specificity, 0.84; sensitivity, 0.73; $\varphi=0.0000(p<0.05), C^{\prime}=0.67$ (the correlation was very strong).

\section{DISCUSSION}

The rise in serum LIF concentrations observed in the patients with stage II EH relative to the healthy controls can be explained by impaired integration of LIFR/CD118 and gp130 signaling under oxidative stress accompanying $\mathrm{EH}$, which affects the catalytic activity of JAK [7] and can stimulate LIF secretion. The elevation of LIF levels at 20:00 o'clock, with a further rise peaking at 2:00 observed in the study participants prior to antihypertensive therapy and also in some patients who had reached the desired blood pressure and were still on antihypertensive drugs is pathogenically relevant: there are

Table 2. The percentage of deviations of blood serum LIF (pg/ml) measured at 14.00, 20.00, 2.00 and 8.00 o'clock (next day) from the initial concentrations measured at 8:00 of the first day in patients with stage II EH in the absence/presence of antihypertensive therapy with or without cardiovascular complications developed in the 5-year follow-up period (Me (Q25\%-Q75\%))

\begin{tabular}{|c|c|c|c|c|c|}
\hline Groups & & $\begin{array}{c}8.00 \\
(\text { day } 1)\end{array}$ & $\begin{array}{l}14.00 \\
\text { (day 1) }\end{array}$ & $\begin{array}{l}20.00 \\
\text { (day 1) }\end{array}$ & $\begin{array}{c}8.00 \\
\text { (day 2) }\end{array}$ \\
\hline $\begin{array}{l}\text { Patients with EH (before therapy), } \\
n=60\end{array}$ & $a$ & $0.91[-1.67-2.54]$ & $20.1[16.7-24.3] * 14.00$ & $\begin{array}{c}34[25.7-33]{ }^{*} 14.00 . \\
20.00\end{array}$ & $\begin{array}{c}1.06[-1.05-3.65] \\
* 20.00 .2 .00\end{array}$ \\
\hline \multirow[t]{2}{*}{$\begin{array}{l}\text { Healthy controls, } \\
n=30\end{array}$} & $b$ & $-1.08[-2.03-1.19]$ & $2.81[1.93-3.22]$ & $0.98[-0.13-2.03]$ & $1.03[-1.72-2.56]$ \\
\hline & & $p(b-a)>0.05$ & $p(b-a)<0.001$ & $p(b-a)<0.001$ & $p(b-a)>0.05$ \\
\hline \multirow[t]{2}{*}{$\begin{array}{l}\text { Patients with EH (one year in treatment), } \\
n=60 \text {, of them }\end{array}$} & c & $0.93[-0.61-2.03]$ & $18.9[15.9-24.1] * 14.00$ & $\begin{array}{c}6.32[2.08-14.4] \\
* 14.00 .20 .00\end{array}$ & $\begin{array}{l}0.76[-0.45-2.21] \\
\quad * 20.00 .2 .00\end{array}$ \\
\hline & & $\begin{array}{l}p(c-a)>0.05 \\
p(c-b)>0.05\end{array}$ & $\begin{array}{l}p(c-a)>0.05 \\
p(c-b)<0.001\end{array}$ & $\begin{array}{l}p(c-a)<0.001 \\
p(c-b)<0.05\end{array}$ & $\begin{array}{l}p(c-a)>0.05 \\
p(c-b)>0.05\end{array}$ \\
\hline \multirow[t]{2}{*}{$\begin{array}{l}\text { 5-year follow-up - MI, ACVE, } \\
n=15\end{array}$} & $c 1$ & $-0.91[-2.83-1.8]$ & $19.9[15.1-23.8] * 14.00$ & $\begin{array}{c}26.5[22.3-28.1] \\
* 14.00 .20 .00\end{array}$ & $\begin{array}{l}0.22[-1.35-2.33] \\
* 20.00 .2 .00\end{array}$ \\
\hline & & $\begin{array}{l}p(c 1-a)>0.05 \\
p(c 1-b)>0.05\end{array}$ & $\begin{array}{l}p(c 1-a)>0.05 \\
p(c 1-b)<0.001\end{array}$ & $\begin{aligned} p(c 1-a) & >0.05 \\
p(c 1-b) & <0.001\end{aligned}$ & $\begin{array}{l}p(c 1-a)>0.05 \\
p(c 1-b)>0.05\end{array}$ \\
\hline \multirow[t]{2}{*}{$\begin{array}{l}\text { 5-year follow-up - no complications, } \\
n=45\end{array}$} & $c 2$ & $0.52[-0.47-1.67]$ & $18.1[14.8-23.8] * 14.00$ & $\begin{array}{c}2.29[-0.35-5.44] \\
' 14.00 * 20.00\end{array}$ & $\begin{array}{l}0.92[-0.62-2.13] \\
* 20.00 .2 .00\end{array}$ \\
\hline & & $\begin{array}{l}p(c 2-c 1)>0.05 p(c 2-b) \\
>0.05 p(c 2-a)>0.05\end{array}$ & $\begin{array}{l}p(c 2-c 1)>0.05 p(c 2-b) \\
<0.001 p(c 2-a)>0.05\end{array}$ & $\begin{array}{c}p(c 2-c 1)<0.001 \\
p(c 2-b)<0.05 \\
p(c 2-a)<0.001\end{array}$ & $\begin{array}{l}p(c 2-c 1)>0.05 \\
p(c 2-b)>0.05 \\
p(c 2-a)>0.05\end{array}$ \\
\hline
\end{tabular}

Note: significant for comparisons with the specified time of blood collection or the group $(a, b, c, c 1, c 2) .^{*}-p<0.001 ;{ }^{\wedge}-p<0.01 ;{ }^{\prime}-p<0.05$. The paired t-test was applied for intragroup comparison of pretreatment results obtained at 8:00, 14:00, 20:00, 2:00 and 8:00 o'clock. The Wilcoxon test was applied for intragroup comparison in the group of patients after one year of treatment and in the healthy controls. The Mann-Whitney U test was applied to compare independent samples. The Wilcoxon test was applied to compare dependent samples. 
reports that LIF-dependent stimulation of STAT3 in endothelial cells triggers the inflammatory cascade [8] and IL1 activation; in turn, this causes a more pronounced $\mathrm{EH}$ progression in the evening (20:00) and at night (2:00), when proinflammatory activity of IL1ra and IL10 is low, through the activation of protein arginine methyltransferase and the inhibition of dimethylarginine, leading to an imbalance in the NO synthesis system. Previously [9], we reported an increased left ventricular mass index, a low mean fiber shortening fraction and a reliable association with pronounced concentric left ventricular hypertrophy in patients with $\mathrm{EH}$ and elevated LIF (>7.5 pg/ml). The observed pathophysiological process led us to hypothesize that patients whose LIF levels were growing between 20:00 and 2:00 in the setting of antihypertensive therapy were at increased risk for cardiovascular complications. The hypothesis was confirmed in the course of this study. LIF-induced cardiac hypertrophy can be characterized by an early reduction in myocardial contractility resulting from the transmural changes in cardiomyocytes [10, 11]. In the early stages of the pathology, elevated LIF serves as a mechanism of compensatory adaptation that stimulates contractility of cardiomyocytes by increasing the activity of T-type $\mathrm{Ca}^{2+}$-channels [12]. Besides, elevated LIF could be potentially protective against the inflammation-induced loss of axons and also promotes survival of oligodendrocytes by stimulating the expression of IGF-1 (insulin-like growth factor 1) [13]. However, the further rise in LIF levels and its circadian fluctuations reported in this study promote poor outcomes in patients with stage $\| \mathrm{EH}$, including potential damage to the myocardium or the brain.

\section{CONCLUSIONS}

The identified patterns of circadian rhythms of blood serum LIF in patients with stage $\| \mathrm{EH}$, namely the rise by $15 \%$ at $20: 00$ and the further rise by $22 \%$ peaking at 2:00, relative to LIF levels at 8:00, can be regarded as pathologic. Their persistence in the setting of antihypertensive therapy could contribute to the progression of hypertension and put the patient at increased risk for cardiovascular complications, in spite of seemingly clinically favorable course of the disease and the success in achieving the target blood pressure. Our findings might lay the groundwork for further research into the role of LIF aimed at establishing a personalized approach to interpreting its dynamics in individual patients. The analysis of LIF circadian rhythms is a candidate diagnostic approach for the assessment of occult progression of the disease in patients with essential hypertension who have managed to achieve their target blood pressure.

\section{References}

1. Mathieu M-E, Saucourt C, Mournetas V, Gauthereau X, Theze N, Praloran V, et al. LIF-Dependent Signaling: New Pieces in the Lego. Stem Cell Rev. 2012; 8 (1): 1-15.

2. Nicola NA, Babon JJ. Leukemia Inhibitory Factor (LIF). Cytokine \& growth factor reviews. 2015; 26 (5): 533-44

3. Wu J, Xia S, Kalionis B, Wan W, Sun T. The Role of Oxidative Stress and Inflammation in Cardiovascular Aging. BioMed Research International. [Internet] 2014: 615312. Available from: https://doi.org/ 10.1155/2014.

4. González GE, Rhaleb N-E, D'ambrosio MA, Nakagawa P, Liu Y, Leung P, Dai X, Yang XP, Peterson EL, Carretero OA. Deletion of interleukin-6 prevents cardiac inflammation, fibrosis and dysfunction without affecting blood pressure in angiotensin II-high salt-induced hypertension. J Hypertens. 2015; (33): 144-52.

5. Bennardo M, Alibhai F, Tsimakouridze E, Chinnappareddy N, Podobed P, Reitz C, et al. Day-night dependence of gene expression and inflammatory responses in the remodeling murine heart post-myocardial. Am J Physiol Regul Integr Comp Physiol. 2016; 311 (6): 1243-1254.

6. Chazova IE, Ratova LG, Bojcov SA, i dr. Diagnostika i lechenie arteria'noj gipertonii. Sistemnye gipertenzii. 2010; (3): 5-26. Russian.

7. Zgheib C, Zouein FA, Kurdi M, Booz GW. Differential STAT3 Signaling in the Heart: Impact of Concurrent Signals and Oxidative
Stress. JAK-STAT. 2012; 1 (2): 101-10.

8. Fujio Y, Maeda M, Mohri T, Obana M, Iwakura T, Hayama A, et al. Glycoprotein 130 cytokine signal as a therapeutic target against cardiovascular diseases. J Pharmacol Sci. 2011; 117 (4): 213-22.

9. Radaeva OA, Simbirtsev AS. Izmenenie urovnya faktora, ingibiruyushchego lejkemiyu, v syvorotke perifericheskoj krovi svyazano s progressirovaniem essencialnoj arterialnoj gipertenzii. Medicinskij akademicheskij zhurnal. 2015; 15 (1): 34-42. Russian.

10. Zouein FA, Kurdi M, Booz GW. Dancing rhinos in stilettos: The amazing saga of the genomic and nongenomic actions of STAT3 in the heart. JAKSTAT. 2013; 2 (3): 101-10.

11. Jia $D$, Cai $M, X i Y, D u S$, Zhenjun $T$. Interval exercise training increases LIF expression and prevents myocardial infarctioninduced skeletal muscle atrophy in rats. Life Sci. 2018; (193): 77-86.

12. Dey D, Shepherd A, Pachuau J, Migue M. Leukemia inhibitory factor regulates trafficking of T-type $\mathrm{Ca} 2+$ channels. Am J Physiol Cell Physiol. 2011; 300 (3): 576-87.

13. Xu L, Long J, Shi C, Zhang N, Lv Y, Feng J, et al. Effect of leukocyte inhibitory factor on neuron differentiation from human induced pluripotent stem cell-derived neural precursor cells. Int J Mol Med. 2018; 41 (4): 2037-49. https://doi.org/10.3892/ ijmm.2018.3418.

\section{Литература}

1. Mathieu M-E, Saucourt C, Mournetas V, Gauthereau X, Theze N, Praloran V, et al. LIF-Dependent Signaling: New Pieces in the Lego. Stem Cell Rev. 2012; 8 (1): 1-15.

2. Nicola NA, Babon JJ. Leukemia Inhibitory Factor (LIF). Cytokine \& growth factor reviews. 2015; 26 (5): 533-44.

3. Wu J, Xia S, Kalionis B, Wan W, Sun T. The Role of Oxidative Stress and Inflammation in Cardiovascular Aging. BioMed Research International. [Internet] 2014: 615312. Available from: https://doi.org/ 10.1155/2014

4. González GE, Rhaleb N-E, D'ambrosio MA, Nakagawa P, Liu Y, Leung P, Dai X, Yang XP, Peterson EL, Carretero OA. Deletion of interleukin-6 prevents cardiac inflammation, fibrosis and dysfunction without affecting blood pressure in angiotensin II-high

salt-induced hypertension. J Hypertens. 2015; (33): 144-52.

5. Bennardo M, Alibhai F, Tsimakouridze E, Chinnappareddy N, Podobed P, Reitz C, et al. Day-night dependence of gene expression and inflammatory responses in the remodeling murine heart post-myocardial. Am J Physiol Regul Integr Comp Physiol. 2016; 311 (6): 1243-1254.

6. Чазова И. Е., Ратова Л. Г., Бойцов С. А., и др. Диагностика и лечение артериальной гипертонии. Системные гипертензии. 2010; (3): 5-26.

7. Zgheib C, Zouein FA, Kurdi M, Booz GW. Differential STAT3 Signaling in the Heart: Impact of Concurrent Signals and Oxidative Stress. JAK-STAT. 2012; 1 (2): 101-10.

8. Fujio Y, Maeda M, Mohri T, Obana M, Iwakura T, Hayama A, et al. 


\section{ORIGINAL RESEARCH I CARDIOLOGY}

Glycoprotein 130 cytokine signal as a therapeutic target against cardiovascular diseases. J Pharmacol Sci. 2011; 117 (4): 213-22.

9. Радаева О. А., Симбирцев А. С. Изменение уровня фактора, ингибирующего лейкемию, в сыворотке периферической крови связано с прогрессированием эссенциальной артериальной гипертензии. Медицинский академический журнал. 2015; 15 (1): 34-42.

10. Zouein FA, Kurdi M, Booz GW. Dancing rhinos in stilettos: The amazing saga of the genomic and nongenomic actions of STAT3 in the heart. JAKSTAT. 2013: 2 (3): 101-10.

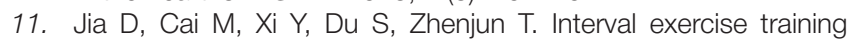

increases LIF expression and prevents myocardial infarctioninduced skeletal muscle atrophy in rats. Life Sci. 2018; (193): 77-86.

12. Dey D, Shepherd A, Pachuau J, Migue M. Leukemia inhibitory factor regulates trafficking of T-type Ca2+ channels. Am J Physiol Cell Physiol. 2011; 300 (3): 576-87.

13. Xu L, Long J, Shi C, Zhang N, LV Y, Feng J, et al. Effect of leukocyte inhibitory factor on neuron differentiation from human induced pluripotent stem cell-derived neural precursor cells. Int J Mol Med. 2018; 41 (4): 2037-49. https://doi.org/10.3892/ ijmm.2018.3418. 